\title{
Impactos ambientales y económicos de las plantaciones de teca Tectona Grandis, en Ecuador
}

\begin{abstract}
(c) (1) (2)(2)
BY NC SA

\section{Environmental and economic impacts of Tectona Grandis teca plantations, in Ecuador}

\author{
Shakespeare Agustín Abarca Córdova. ${ }^{1}$, Patricio Alejandro Merino Córdova. ${ }^{2}$, Byron
}

Fabricio Estupiñán Cox, ${ }^{3} \&$ Daniel Eriel Izquierdo García. ${ }^{4}$

\begin{abstract}
.
DOI: https://doi.org/10.33262/cienciadigital.v3i1.274

Plantations can be both good and bad, and therefore the responsibility to review concepts and adopt good practices in all dimensions of sustainable development. It is about establishing appropriate bases to continue the reforestation with greater knowledge to enhance the positive impacts and reduce or eliminate the negative impacts that these plantations may have.

Those responsible for the development of plantations in Ecuador are creating an important knowledge base through research and experience to make good, better, forest plantations.

The discussion about the advantages and disadvantages of the plantation suffers from a fundamental error: the comparison with the native forests, when it is not reasonable to make these comparisons. Planted forests and natural forests are not equivalent. In the absence of local experiences or systems of indicators, it is advisable to use as a first guide the principles and criteria in force for forest plantations applied by the Forest Stewardship Council (FSC), and thus to orientate oneself on what is a good reforestation organization and what is a good forest plantation
\end{abstract}

\footnotetext{
${ }^{1}$ Universidad Técnica Luis Vargas Torres, Esmeraldas, Ecuador, shak63@ hotmail.es

2 Universidad Técnica Luis Vargas Torres, Esmeraldas, Ecuador, patric_merino@hotmail.com

${ }^{3}$ Universidad Técnica Luis Vargas Torres, Esmeraldas, Ecuador, byrondj627@hotmail.com

${ }^{4}$ Universidad Técnica Luis Vargas Torres, Esmeraldas, Ecuador, jones_izquierdo23@ hotmail.com
} 
Keywords: Teak (Tectona Grandis), Environmental Impact, Forestry, Socioeconomic, Plantation.

\section{Resumen}

Las plantaciones pueden ser tanto buenas como malas, y por lo tanto, la responsabilidad de revisar conceptos y adoptar buenas prácticas en todas las dimensiones del desarrollo sostenible. Se trata de establecer bases apropiadas para continuar la reforestación con un mayor conocimiento para mejorar los impactos positivos y reducir o eliminar los impactos negativos que estas plantaciones puedan tener.

Los responsables del desarrollo de plantaciones en Ecuador están creando una importante base de conocimientos a través de la investigación y la experiencia para hacer que las plantaciones forestales sean mejores y mejores.

La discusión sobre las ventajas y desventajas de la plantación sufre de un error fundamental: la comparación con los bosques nativos, cuando no es razonable hacer estas comparaciones. Los bosques plantados y los bosques naturales no son equivalentes. En ausencia de experiencias locales o sistemas de indicadores, es aconsejable utilizar como primera guía los principios y criterios vigentes para las plantaciones forestales aplicados por el Forest Stewardship Council (FSC), y así orientarse sobre lo que es una buena reforestación. Organización y qué es una buena plantación forestal.

Palabras clave: Teca (Tectona Grandis), Impacto Ambiental, Forestal, Socioeconómico, Plantación.

\section{Introductión.}

We can mention that plantations specifically of Tectona Grandis can have positive as well as negative impacts, and therefore the responsibility to review concepts and adopt considerable practices in all extensions of sustainable development. It is about establishing appropriate bases to continue with socioeconomic and environmental research with greater knowledge to enhance the positive impacts and reduce or eliminate the negative impacts that these plantations may have. Those responsible for the development of plantations in the provinces of Los Ríos, Santo Domingo and Esmeraldas are creating an important knowledge base through research and experience for the development of better, forest plantations.

\section{The expansion of teak plantations in Ecuador}

Ecuador is among the ten countries with the greatest diversity in the world, it is also among the countries of Latin America with a higher rate of deforestation in proportion to the size of 
its territory. According to the Ministry of the Environment, the main cause would be the expansion of the agricultural frontier.

However, recent studies indicate that the crops of the small farmers, who are the ones who feed the country, have not grown, whereas the agroindustry, with the African palm, sugarcane, and monocultures of eucalyptus, pines and teak, has grown quickly, obviously causing forest deforestation to which we refer. In this context, Ecuador exported 190 thousand square meters of this wood in 2014, with all the environmental impacts that this entails. The government of Ecuador is responsible for the promotion and expansion of teak in the country to the detriment of agro biodiversity and the replacement of native ecosystems, such as the dry forest in the provinces of Guayas and Manabí.

The teak plantations in Ecuador are not destined for the internal consumption of this wood. All teak is exported. Exports to India represent 95 percent of the total teak in Ecuador, which means between 150 and 160 thousand tons of teak per year, which represents about US \$ 30 million of profit for the industry. The economic benefits for the places where this wood is produced are very few due to the lack of labor generated by this crop, the lack of social investment by producers, the loss of food sovereignty and the scarcity of water that it entails.

\section{Devastating effects}

In the province of Guayas, the area with the largest number of plantations of teak monocultures in the country, mostly in the cantons of Balzar, the landscape of teak is bleak. There are no animals in a teak monoculture plantation. The peasants of the place testify that it does not serve as a shelter for birds: "no bird nests here". Teak trees do not interact positively with the environment, because they are fast-growing absorb large amounts of water and nutrients, in addition to need agrochemicals. The government of India, for its part, asks that the logs and blocks of this wood be fumigated in the place of origin (where the product comes from) with methyl bromide, whose use is prohibited in Ecuador due to its high toxicity.

Therefore, Ecuador has proposed to fumigate with aluminum phosphide, a highly dangerous element, since when it comes into contact with air, it releases a gas called Phosphine, which is very toxic to the body. In the field of Public Health, this pesticide is responsible for a high rate of deadly diseases for affected populations and spaces. The use of this chemical to meet the demands of the industry therefore implies a very high risk to workers, neighboring populations and the environment.

The dispute about the advantages and disadvantages of the plantation suffers from a fundamental error: the comparison with the native forests, when it is not reasonable to make these comparisons. Planted forests and natural forests are not equivalent. In the absence of local experiences or systems of socio-economic and environmental indicators, it is advisable to use as a first guide the principles and criteria in force for forest plantations applied by the 
Forest Stewardship Council (FSC) and thus be guided on what is a good reforestation organization. and what is a good forest plantation.

Table 1. Tala, shipowners and workers in the production of Teak tree from the province of Tarragona (2009).

\begin{tabular}{cccc}
\hline & Talas (Tons) & Shipowners & Talers \\
\hline Esmeraldas & 275,25 & 12 & 9 \\
Santo Domingo de los Tsáchilas & 262,15 & 90 & 268 \\
Los Ríos & 647,76 & 37 & 150 \\
\hline
\end{tabular}

Source: BCE.

Elaborated by: Group of investigators.

\section{The principles and criteria for a good plantation.}

Even when there are critical judgments about forest certification, and the process is only a tool to improve the sustainability of the management of natural and planted forests, the current principles and criteria for forest plantations applied by the FSC can guide which is a good reforestation organization and what is a good forest plantation. If we refer to the principle 10 of the FSC and its respective criteria, we could define a good plantation as that in which:

"Both in its establishment and in its administration, the laws are complied with, the tenure rights of the land are respected, the rights of indigenous communities are respected and opportunities are created for them, the rights of workers and communities in the area of influence of reforestation are respected, efficient use is made of the goods and services that the plantation generates, the environmental impacts are reduced, they are carefully planned and the execution plans are fulfilled, the impacts of the plantation are monitored, in a permanent process of learning and the management is done in an adaptive way, by the learning that the monitoring implies "(FSC, 1994.

These requirements correspond to the generic principles of the FSC. But additionally, a good plantation, meets the criteria of principle 10, which can be summarized in the following:

The management objectives of the plantation are clear and documented and the management is oriented towards compliance.

The design and planning of plantations should promote the protection and conservation of natural forests, and not increase pressures on them (wildlife corridors, protection of river 
beds, and mosaic of stands of different ages, rotation, and compliance with the patterns of the stands within their natural landscape.

The plantations have clear elements of biodiversity, to improve stability (size and spatial distribution of management units within the landscape, number and genetic composition of species, age classes and structures and types of products).

Selection of species based on the site and management objectives. Exotic species are used when their performance is higher than that of native species (monitoring mortality, diseases or insect damage and adverse ecological impacts).

A proportion of the total area of forest management (which will be determined in the regional standards) should be managed in such a way that the natural forest cover of the site is restored.

Measures to maintain or improve the structure, fertility and biological activity of the soil. The techniques, rate of harvest, maintenance and construction of roads and the selection of species should not degrade the soil or water or its distribution.

Minimize damage from pests, diseases, fire and the introduction of invasive plants. (Integrated pest management, prevention and biological control instead of pesticides and chemical fertilizers).

The monitoring should include a regular assessment of the ecological and social impacts on the site and outside it. Large-scale species should not be planted until the tests have shown that they are adapted to the site, are not invasive and do not have negative ecological impacts.

\section{The Territories of Original Peoples.}

Reforestation projects must respect the rights of the original peoples. The positive right, western, recognizes the properties registered in the registries of property of each country. However, there are many territories that are claimed by indigenous communities, which have no support in the legislations of their countries, and whose territories are not delimited. This has been the case with considerable areas of forest plantations of Pine insigne in the centralsouthern region of Chile.

The companies have valid titles, but on them the indigenous communities claim ancestral rights. Due to the lack of alternative conflict resolution strategies and the lack of willingness of companies to dialogue with indigenous communities, there have been occupations, forest fires, violent confrontations, prison. Occasionally, the surfaces in conflict are smaller percentages of the planted areas. However, companies that do not want to set precedents are strictly based on legal rights and do not recognize any original rights. As we will see, these situations have other serious social consequences. 
Respect for Cultural Places and Medicinal and Ritual Species.

To avoid negative impacts of forest plantations, their promoters must respect the cultural and religious places of the indigenous and ladino rural communities. This implies giving access to local inhabitants to traditional places of ceremonies and regulating traditional rights such as fishing and hunting. Communities must also maintain their traditional rights to the collection of non-timber products and medicinal plants. In extreme situations, reforested companies have practically eliminated all natural vegetation, including streams and minor water courses, eliminating the possibility that traditional doctors can communicate with their spirits and have nearby sites for collecting medicinal plants and rituals (as the Canelo, Drymis winteri, in Mapuche communities of the $\mathrm{X}$ region in Chile). The costs associated with these conflicts can be quite high and it is advisable to look for alternative strategies for handling conflicts outside the courts.

\section{Workers' Rights}

There are differences, as identified by Rusch et al (2004), between being a worker of a forestry company, to wish that the children continue with the tradition, since it supposes improvement of the indexes of human development and income. When reforestation companies and organizations limit themselves to meeting legal minimums (or even do not even meet those minimums), the social impacts are not different from any other enterprise in which there is no corporate social responsibility. The forestry developments fear to maintain good salaries, train their workers, because they risk not being competitive and working with very high costs. On the other hand, the reduction of labor conflicts, the increase in productivity and the lower rotation of workers are examples of positive impacts of corporate social responsibility, it allows to capitalize investments in training of human resources.

\section{Relations and Rights of Communities}

There must be a favorable relationship between social development and sustainable local development, with investments made in reforestation. In many countries, the concentrations of investment in forest management and reforestation coincide with pockets of poverty, and with regions where the product is exported, capital is remitted outside the region, while poverty increases and local inhabitants they also lack health, education, food security and social security services. Forest plantation developers must support communities and respect their rights. Many times the disputes of transit easements, water rights, collection rights, are frequent. To avoid negative impacts on the communities, it is necessary to have clearly regulated relations with them, to have designated representatives in companies and corporations and to request the designation by local representative representatives, who maintain a permanent dialogue and not only to resolve conflicts. Companies and reforested corporations can contribute to the planning of local development and the creation of 
opportunities for education, health, business and jobs additional to those created by forestry itself.

\section{Local Employment Generation}

Undoubtedly, forest plantations create local employment. But you have to be realistic about the potential for employment. The establishment, management and use of plantations do not have high employment intensity. But to judge the reforestations from this point of view, it is necessary to compare with the local alternatives and ask: who generates more work, extensive cattle ranching or reforestation? How is the generation of employment along the entire productive chain? From the nursery, to the final product in the industry? What forest services are included in the generation of employment? What is the job offer in a certain region, to decide on the technology to be used in operations? How much indirect employment is generated? If everything is left to chance, without adequate strategies or planning, the employment effect can be reduced, temporary and of low quality (from the point of view of human development).

On the contrary, if the reforestation effort is due to a regional strategy, it should be accompanied by specialization of the work, creation of forest services, operation as a forest cluster (integrating all elements and members of the production chain

\section{The profitability of Reforestation}

In the work of Rush et al (2004) there is concern about the possibilities of small and medium forest plantation owners. It seems that profitable forestry activity is only feasible for large owners. We must distinguish between what is a profitable forest operation and what is an operation that allows, for its cash flow and its magnitude, sustain a family in a sustainable manner.

Any well-planned forestry operation with efficiency in marketing and markets can be profitable. However, a family requires income every week, every month and every year and if the surface they take advantage of is too small, they can not subsist on it. It is necessary to have a minimum surface area and a regular cash flow. Many solutions are offered for this, such as silvopastoral and agroforestry systems, sale of environmental services and tourism, mechanisms for buying wood in advance, horizontal integration to lower operating costs, vertical integration to have better access to markets, etc. Another aspect that needs to be highlighted, that at present, there are at least two kinds of projects: those that offer reforestation as an investment opportunity and those that offer reforestation as the start of forestry production companies. In recent years, offers of green investments in reforestation have appeared in different countries. These offers contain a proposal for species, growth rate, development and execution costs and final product prices. There are serious projects of groups that want to develop a sustainable forest production company. In these cases they 
work with real figures and do not offer anyone to become millionaires in the short term. There are, however, other cases in which the promoters of the projects offer non-existent growth rates (at the most exaggeratedly high), therefore, very low turnover ages and also non-existent product prices. The result is that they offer hectares planted and maintained at prices of US \$20 to 50 thousand per hectare. Many of these promoters, once they have managed to place their stock offer, disappear and ruin the investment based on imaginary assumptions. This problem occurred with Teca in Costa Rica and Panama and we must prevent it from happening again.

\section{Social Capital Formation}

The development of reforestation, if it fails to create social capital, does not guarantee economic development and sustainable human development. This implies that a special effort is required from the authorities and companies, for training human resources, creating institutions, organizing capacities, local leadership capacities. Thus the result will not only be to form a forest resource, to benefit the flora and fauna, to create employment, to create tourism, but also to create leadership, to create institutions that allow communities to take their own destiny into their own hands. There are interesting cases, such as that of the community of Hojancha in Costa Rica. The community first went through a process of training local leadership, strengthening the ties of the inhabitants with their territory, appropriation by the local institutional system, capacity to formulate, manage and manage projects.

This way the community will be able to reforest and achieve the development of the local industry, protect watersheds and recover degraded forests, recovering the potential water producer of the basin, protect forests and create ecotourism and environmental education capacity. In this sense, in Hojancha or in Neuquén, in Petén or in Chubut, in Río Negro or in Darién, in Santa Cruz and in the savannas of Venezuela, forestry development initiatives must integrate much more than the technical and logistical part of the plantations. To your strategies.

\section{Income from Products and Income from Environmental Services}

Forest plantations can produce high, regular or low incomes, like any other investment. But it must be made clear that reforestation, although it can have a reasonable profitability, is far from obtaining the interest rates of trade, capital speculation, technological investments, etc.

\section{Conclusions}

- A reforestation is not good or bad a priori. A reforestation is good or bad according to principles and clear criteria in environmental, social and economic matters. It is 
not a matter of saying, plantations are good or bad, but to say that the plantation of Teak is good or bad, sustainable or not sustainable.

- We know most of the variables that build a good plantation project and we have more and more knowledge to make most projects sustainable. Forest plantations in Patagonia seem to be a reasonable alternative to land use and business for different levels of investors.

- It is our responsibility as communities, as entrepreneurs, as researchers and as regional and national government, that this option be healthy.

\section{Bibliographic references.}

Carrere R. 1998.Ten Replies to Ten Lies. Briefing Paper. Plantations Campaign. World Rainforest Movement.

De Camino R, A. Bárcena. 1995. Improving the effectiveness of international cooperation for sustainable development in Latin America. In Cortés, de Camino, Contreras. Readings of the workshop on government policy reform for forest conservation and development in Latin America. CIFOR, USAID, IICA, EPAT-MUCIA, IDB, WB. Washington.

De Camino R y G. Bukowski. 1995. Impactos ambientales de las plantaciones forestales. Revista Forestal Centroamericana 101. Turrialba.

De Camino R. 1999. Latinoamérica. Plantations and natural forests. The need for a balanced approach. IUFRO Latin American Forest Congress. Valdivia. Chile.

De Camino R, G. Mes y J. Breitling 2004. Sobre los productos y servicios ambientales del bosque y plantaciones forestales. Ambioentico no. 135. UNA. Costa Rica

Duek J. 1981. Evaluación del impacto ambiental. Plan de manejo conservacionista de las microcuencas de Cocorotico y El Tejar. CONARE. Universidad Simón Bolívar. Venezuela.

FSC 1994. FSC Principles \& Criteria of Forest Stewardship. http://www.fsc.org/en/about/policy_standards/princ_criteria

Loguercio G. 2005. Acciones emprendidas en Patagonia para la captura de Carbono entre 1990 y 2004. Informe Técnico. Fundación Bosques de la Patagonia. 39 pgs.

Loguercio G. y F. Deccechis 2006. Forestaciones en la Patagonia Andina: potencial y desarrollo alcanzado. Nota técnica. Patagonia Forestal, CIEFAP. Año XII, No 1. Esquel, Argentina. 4-6. 


\section{Para citar el artículo indexado.}

Abarca S., Merino P., Estupiñán B, \& Izquierdo D. (2019). Impactos ambientales y económicos de las plantaciones de teca Tectona Grandis, en Ecuador. Revista electrónica Ciencia Digital 3(1), 118-127. Recuperado desde: http://cienciadigital.org/revistacienciadigital2/index.php/CienciaDigital/article/view/274/658

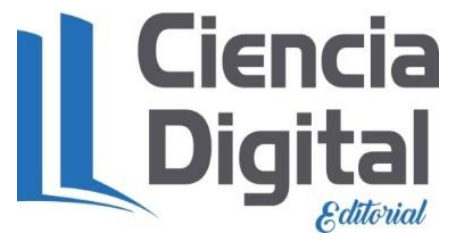

El artículo que se publica es de exclusiva responsabilidad de los autores y no necesariamente reflejan el pensamiento de la Revista Ciencia Digital.

El artículo queda en propiedad de la revista y, por tanto, su publicación parcial y/o total en otro medio tiene que ser autorizado por el director de la Revista Ciencia Digital.
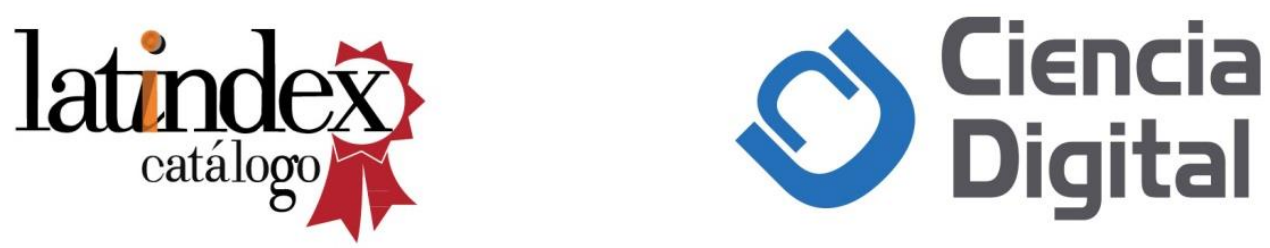